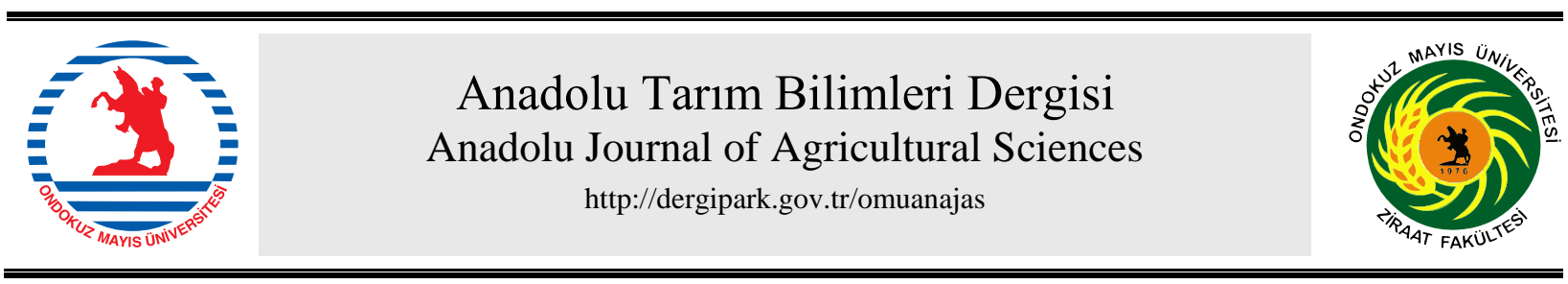

\title{
Araştırma/Research
}

Anadolu Tarım Bilim. Derg./Anadolu J Agr Sci, 36 (2021) ISSN: 1308-8750 (Print) 1308-8769 (Online) doi: 10.7161/omuanajas.905733

\section{Samsun Piyasasında Deri ve Plastik Bidonda Satışa Sunulan Tulum Peynirlerinin Bazı Kalite Özellikleri}

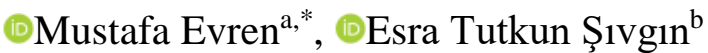 \\ ${ }^{a}$ Ondokuz Mayıs Üniversitesi, Mühendislik Fakültesi, Gıda Mühendisliği Bölümü, Samsun, Türkiye \\ ${ }^{b}$ Ondokuz Mayıs Üniversitesi, Samsun, Türkiye
}

*Sorumlu yazar/corresponding author: mustafaevren@hotmail.com

Geliş/Received 30/03/2021 Kabul/Accepted 24/05/2021

\begin{abstract}
ÖZET
Bileşiminde bulunan protein, kalsiyum, yağ ve vitaminler sütü insan beslenmesinde çok önemli bir gıda maddesi haline getirmektedir. Ancak süt, çeşitli koruma yöntemlerine tabi tutulsa bile hayvandan sağıldıktan sonra tüketilmesine kadar olan her aşamada kimyasal ve mikrobiyolojik bulaşmaya ve bozulmalara uğramaktadır. Sütün peynire işlenmesi bu riskleri azaltıp daha uzun ömürlü bir ürün haline getireceği gibi, duyusal ve besleyici yönden daha yararlı bir gıda elde edilmesini sağlamaktadır. Peynir ülkemizde çok eski zamanlardan beri üretilip tüketilmektedir. Peynir üretimi önceleri genellikle ev ölçeğinde, küçük aile işletmelerinde, mandıralarda ve köylerde gerçekleştirilirken, günümüzde bu tip üretimler hala devam etmekle birlikte bunun yanında endüstriyel boyutta da geniş bir üretim yapılmaktadır. Ülkemizde çok fazla çeșitte ve tipte peynir üretilmektedir. Tulum peyniri ülkemize özgü olan, halk tarafından oldukça sevilerek tüketilen, üretim ve tüketim açısından ilk sıralarda yer alan bir peynir tipidir. Üretiminde salamuralı ve kuru üretim gibi farklı yöntemler uygulanmakla birlikte, olgunlaştırma, ambalaj ve satış materyali olarak bez, deri Tulum ve plastik bidon gibi farklı materyaller de kullanılmaktadır. Piyasada çoğunlukla deri Tulum ve plastik bidona rastlanılmakla birlikte diğer üretimler daha çok yöresel üretim ve tüketimleri kapsamaktadır. Bu çalışmada Samsun piyasasında satışa sunulan 35 adet deri Tulum peyniri ve 28 adet plastik bidon Tulum peynirinde fiziksel, kimyasal, mikrobiyolojik ve duyusal analizler yapılmıştır. Analize alınan örneklerden deri Tulum peynir örneklerinin 16 adedi (\% 46), plastik bidon Tulum peyniri örneklerinin 5 adedi (\% 18) kuru madde açısından Türk gıda kodeksi peynir tebliğine uygun bulunmuştur. Yağ miktarı açısından aynı tebliğe göre deri Tulum peynir örneklerini 9 adedi (\% 26) yarım yağlı, 26 adedi az (\% 74) az yağlı, plastik bidon Tulum peyniri örneklerinin tamamı (\% 100) az yağlı peynir grubunda yer almıştır. Tuz miktarı yönünden yalnızca 3 adet deri Tulum peyniri örneği sınır değerin üzerinde bulunmuştur (\% 9). Analizler sonucunda deri Tulum ve plastik bidon Tulum peynirleri fiziksel, kimyasal, mikrobiyolojik ve duyusal nitelikler açısından büyük farklılıklar göstermiştir. Bu durum üretimde standart bir yöntem kullanılmamasının bir sonucu olarak değerlendirilebilir. Güvenli bir gıda tüketimi için Tulum peyniri üretiminde standartlaşmaya gidilmesi gerekmektedir.
\end{abstract}

Some Quality Characteristics of Tulum Cheese Sold in Leather and Plastic Drums in Samsun Market

\section{ABSTRACT}

Milk turns out to be an important food for human nutrition including protein, calcium, fats and vitamins. However, even if various protection methods utilized for milk, it can be contaminated and spoilage chemically and microbiologically at every stage from milk to consume. Processing milk into cheese will reduce these risks and make it a long shelf life product as well as beneficial food in terms of nutritional and sensory aspects. Cheese has been produced and consumed since ancient times. Cheese

Anahtar Sözcükler: Deri Tulum peyniri Plastik bidon Tulum peyniri Bileşim Kalite
Keywords: Leather Tulum cheese Plastic drum Tulum cheese Composition 
production generally carried out at home scale in a small family firm, dairies and villages and today this Quality kind of production continue; besides a wide range of products is made on an industrial scale. Many varieties and types of cheese are produced in our country. Tulum cheese is a type of cheese that is unique to our country, consumed with love by the public and ranks first in terms of production and consumption. Different production methods for Tulum cheese are utilized such as brine and dry production and also different material such as clothes, leather overalls and plastic drums are used as maturation, packaging and sales materials. Although leather overalls and plastic drums are generally found in the market, other production frequently involves local production and consumption. In this research, physical, chemical, microbiological and sensory analyzes were performed on 35 leather Tulum cheese and 28 plastic drum Tulum cheese sold in Samsun market. Among the samples included in the analysis, 16 (46\%) of the leather Tulum cheese samples and 5 (18\%) of the plastic drum Tulum cheese samples were found to comply with the Turkish food codex notification on cheese in terms of dry matter. In terms of the amount of fat, according to the notification, 9 (26\%) of leather Tulum cheese semi-skimmed, 26 (74\%) of them low-fat and plastic drum cheese samples (100\%) were included in the low-fat cheese group. Only three leather Tulum cheese samples were found above the limit value (9\%).As a result of the analysis, leather overalls and plastic drums Tulum cheeses showed big differences in terms of physical, chemical, microbiological and sensory qualities. This situation can be evaluated as a result of not using a standard production method. For safe food consumption, it is necessary to standardize the production of Tulum cheese.

\section{Giriş}

İçerdiği zengin besin öğeleriyle süt insanlar için değerli bir besin olduğu kadar mikroorganizmalar için de iyi bir besin kaynağıdır. Meme dokusunda iken steril olan süt, sağımla birlikte mikroorganizmalarla kontamine olur. Süte bulaşan mikroorganizmalar hızla çoğalarak kısa zamanda sütün yapısını bozup dayanıklılığını azaltır. Bu nedenle muhafazası zor olduğundan, dayanıklılık süresini artırmak ve naklini kolaylaştırmak için insanoğlu sütü, eskiden beri çeşitli ürünlere işlemiştir. Bu yüzden gıdalarımızın birçoğunun yapılışı eskilere dayanır (Kamber, 2006). Tulum peyniri; Kaşar ve Beyaz peynirin yapılmadığı yerlerde yağ üretiminden geriye kalan sütün değerlendirilmesi amacıyla yaylalarda yapılırdı fakat son y1llarda büyük tüketim merkezlerinde artan talebi karşılamak amacıyla mandıra ve süt işletmelerinde de üretim yapılmaktadır (Tarakçı ve ark., 2005; Tekinşen ve Akar, 2017). Peynirin ismi, hayvan derisi anlamına gelen "Tulum" kelimesinden türemiştir (Demirtaş ve Coşkun, 2018). "Tulkuk" veya "tulûk" olarak adlandırılan Tulum; oğlak, süt kuzusu, koyun veya keçi derisinden yapılmaktadır (Durlu Özkaya ve Gün, 2007). Tulum peyniri, "hammaddenin peynir mayası kullanılarak pıhtılaştırılması ile elde edilen telemenin fermentasyonunu takiben ufalanıp tuzlanmasi, daha sonra gidaya temasa uygun bir ambalaj malzemesine veya deri Tulumlara sıkıca basılarak üretilen ve olgunlaştırıldıktan sonra piyasaya arz edilen çeşidine özgü karakteristik özellikler gösteren peynir" olarak tanımlanmaktadır (Anonim, 2015).

Türkiye 100 'den fazla peynir çeşidi üretmektedir ve Tulum peyniri en çok tüketilen üç peynir çeşidinden biridir. Türkiye'de çeşitli bölgelerde üretim olmasına rağmen, en popüler türleri olanlar Erzincan, Afyon, İzmir, Çorum ve Konya'da üretilmektedir. Tulum, olgunlaştırılmış bir peynir türüdür ve benzersiz dokusal ve duyusal özelliklere sahiptir (Tomar, 2019; Yerlikaya ve Kınık, 2013). Erzincan Tulum peyniri, Divle Obruğu Tulum peyniri, Türk Patent Enstitüsü tarafından coğrafi işaret statüsü almıştır (Çakır ve Çakmakçı, 2018; Saygılı ve ark., 2020; Toklu ve Pekerşen, 2019). Tulum peyniri, Türkiye'de daha çok çiğ koyun sütünden üretilen geleneksel peynirlerden biridir. Plastik bidon veya keçi derisi torbasında olgunlaştırıldığı gibi tahta veya çömlekler Tulum peynirlerinin olgunlaştırılmasında kullanılmaktadır. Bazı tüketiciler, çiğ sütten üretilen peynirlerin patojen mikroorganizmalar açısından güvenli olmadığına inanmaktadır (Hayaloğlu ve ark., 2007; Tekin ve Güler, 2019; Sert ve Akın, 2008). Genellikle çiğ sütten üretilen Tulum peynirlerinin kalitesini ve raf ömrünü etkileyen birçok faktör bulunmaktadır. Bunlardan biri de ambalaj materyalinin yapısıdır. Önceleri hijyenik olmayan hayvansal kökenli Tulumlara basılan peynirler daha sonraları plastik bidonlara basılmaya başlanmışır. Bu konuda yapılan çalışmalar oldukça sınırlıdır (Demir ve ark., 2017). Tulum peyniri üretiminde çoğunlukla geleneksel yöntemler uygulanmakla birlikte starter kültür kullanılarak da üretim gerçekleştirilmektedir. Yapılan çalışmalar starter kullanılarak yapılan üretimlerde son ürünün fiziksel, kimyasal ve duyusal özelliklerinin geleneksel yöntemle üretilenlere göre daha iyi olduğu belirlenmiştir (Arıcı ve Şimşek, 1991; Ateş ve Patır, 2001; Eser ve ark., 2020; Öner ve ark., 2005; Tulukoğlu ve ark., 2020). Farklı 1sı ve starter kültür kombinasyonları denenerek, Tulum peyniri üretiminde hızlı olgunlaştırma olanaklarının araştırıldığı bir çalışmada ideal organoleptik özelliklere sahip ürün üretildiği ve bu uygulamaların teknolojik Tulum peyniri üretiminde kullanılabileceği önerilmiştir (Duman Aydın ve Gülmez, 2008). Tulum peyniri yer yer karakteristik olan doğal küflü tadı ve aroması için tercih edilmektedir. Olgunlaşma esnasında Tulum peynirine doğal olarak kontamine olan küfler gelişir ve bu şekilde olgunlaşma sürecine katkı sağlamış olurlar. Tulum peyniri üretiminde geleneksel olarak koyun ve keçi sütü kullanılırken, son yıllarda tüketim miktarının artmasıyla birlikte inek sütü de tercih edilmektedir (Demirtaş ve Coşkun, 2018; Erdoğan ve ark., 2003). Tulum 
peyniri üzerinde yapılan araştırmalar, bunların kimyasal ve mikrobiyolojik özelliklerine ve farklı ambalaj malzemelerinin olgunlaşma sırasında Tulum peynirinin çeşitli özelliklerine etkilerine odaklanmıştır (Arslaner ve Türkmen, 2020; Çakır ve Çakmakçı, 2018).

\section{Materyal ve Yöntem}

\subsection{Materyal}

Araştırmada Samsun ilinde farklı satış noktalardan alınan 35 adet deri Tulum peyniri, 28 adet plastik bidon Tulum peyniri olmak üzere toplam 63 adet Tulum peyniri örneği materyal olarak kullanılmıştır. Tulum peyniri kitlesinin merkeze yakın noktasından, havaya açık olmayan kısmından aseptik koşullarda steril cam kavanozlara yaklaşık 150-250 g arasında örnek alınmış ve soğuk zincirde laboratuvara getirilerek analizleri yapılmıştır

\subsection{Yöntem}

Örneklerde fiziksel ve kimyasal analizler olarak toplam kuru madde (AOAC, 1995), yağ analizi (Oysun, 1991), protein analizi (Cemeroğlu, 2010), tuz analizi (Cemeroğlu, 2010), kül miktarı analizi (AOAC, 1997), asitlik analizi (laktik asit cinsinden) (Cemeroğlu, 2010) yapılmış, pH değeri dijital pH-metre (Cyberscan PC 510, Singapur) ile ölçülmüştür. Kuru maddede tuz oranı, tuz miktarlarının kuru maddeye oranlanmasıyla, kuru maddede yağ oranı, yağ miktarlarının kuru maddeye oranlanmasıyla hesaplanmıştır.

Mikrobiyolojik analiz amaciyla gelen örneklere serum fizyolojik (8.5 g NaCl/l) ilave edilerek Stochmacher'de (AES Chemunex Smasher) 120 saniye boyunca homojenize edilmiştir. Seyreltilen örnekler seri dilüsyona tabi tutulmuştur. Mikrobiyolojik analizler olarak toplam mezofilik aerobik bakteri sayımı (TMABS) için PCA (Lab M, LAB 149) besiyeri kullanılmış ve ekim yapılan petriler $28^{\circ} \mathrm{C}^{\prime}$ de inkübatörde (Nüve cooledin cubator ES110) inkübasyona tabi tutulmuştur (Ünlütürk ve Turantaş, 2002). Laktik asit bakterilerinin sayımı için, MRS ve M17 agar $\left(37^{\circ} \mathrm{C}\right.$ 'de 48 saat) besiyerine dökme plak yöntemiyle ekim yapılmıştır (Caridi, 2003). Maya-küf sayımında (MKS) PDA (Lab M, LAB 98) besiyerinde $28^{\circ} \mathrm{C}$ 'de inkübasyon işlemi uygulanmış, 3.gün ve 5.gün sayım yapılmıştır (Aydar, 1999). Koliform bakteri sayımında (KS) 10-1 dilüsyonundan Coliform Count Plate petrifilmlere (3M Petrifilm Co.Uk.) $1 \mathrm{ml}$ ekim yapılmış, $36^{\circ} \mathrm{C} \pm 1$ 'de $24 \pm 1$ saat inkübatörde inkübasyona bırakılmıştır. İnkübasyon sonucunda koyu kırmızı renkli koloniler sayılmıştır (Schraft ve Waterwort, 2005). E.coli sayımında (ES) 10-1 dilüsyonundan E.coli Count Plate petrifilmlere (3M Petrifilm Co.Uk.) $1 \mathrm{ml}$ ekim yapılmış, $36^{\circ} \mathrm{C} \pm 1$ 'de $24 \pm 1$ saat inkübasyona bırakılmıştır. İnkübasyon sonucunda mavi renkli koloniler sayılmıştır (Schraft ve Waterwort, 2005). Enterobacteriaceae spp. sayımında (EBS) Enterobacteriaceae Count Plate petrifilmlere (3M Petrifilm Co.Uk.) $1 \mathrm{ml}$ ekim yapılmış, $36^{\circ} \mathrm{C} \pm 1$ 'de $24 \pm 1$ saat inkübasyona bırakılmıştır (Silbernagel ve Lindberg, 2003). Staphylococcus aureus sayımında (STS) Staph. Express Count Plate petrifilmlere (3M Petrifilm Co.Uk.) $1 \mathrm{ml}$ ekim yapılmış, $36^{\circ} \mathrm{C} \pm 1$ 'de $24 \pm 1$ saat inkübasyona bırakılmıştır. İnkübasyon sonucunda mor renkli koloniler sayılmıştır (Silva ve ark., 2005). Pseudomonas spp. sayımı (PS) nalidiksik asit (Merck, 1.06219) ilave edilen Cetrimite Agar (Merck, Darmstad, Germany) kullanılarak yapılmış, petri kapları $35^{\circ} \mathrm{C}$ 'de $48-72$ saat inkübe edilmiş, inkübasyondan sonra mavi-yeşil pigmentli kolonilerin sayımı yapılmıştır (Goto and Enomoto, 1970). Proteolitik bakteri sayımında (PB) örnekler Calcium Caseinate Agar besiyerinde $28-30^{\circ} \mathrm{C}$ 'de 48 saat inkübasyona bırakılmış, inkübasyon sonunda sonunda etrafı berrak zonlu koloniler sayılmıştır (Halkman, 2005). Lipolitik bakteri sayımında (LB) örnekler Tributyrin Agar besiyerinde $28-30^{\circ} \mathrm{C}$ 'de 48 saat inkübasyona bırakılmış, inkübasyon sonunda sonunda etrafi berrak zonlu koloniler sayılmıştır (Halkman, 2005). Salmonella varlık-yokluk testi (SV) SalmonellaShigella Agar (Merck, VM714267 649) besiyerinde $36^{\circ} \mathrm{C} \pm 1$ 'de $48 \pm 1$ saat inkübasyona birakılmış, inkübasyon sonucunda gelişen koloniler değerlendirilmiş̧ir (Andrews ve ark., 2001). Listeria varlık-yokluk testi (LV) Listeria Plate petrifilmlere (3M Petrifilm Co.Uk.) $1 \mathrm{ml}$ ekim yapılmış, $36^{\circ} \mathrm{C} \pm 1$ 'de $24 \pm 1$ saat inkübasyona bırakılmış, inkübasyon sonucunda gelişen koloniler değerlendirilmiştir (Nyachuba ve Donnely, 2007).

Duyusal panelde “eşleştirerek mukayese testi” kullanılmış kesit ve görünüş ( 25 p), yapı (25 p), koku (25 p), tat $(25 \mathrm{p})$, toplam (100 p) olarak değerlendirilmiştir ve testler 10 panelist tarafından gerçekleştirilmiştir.

\section{3 İstatistiksel Analiz}

Yapılan çalışma sonucunda elde edilen verilerin istatistiksel olarak değerlendirilmesinde IBM SPSS Statistics V.21 paket programı kullanılmıştır. Deri tulum ve plastik bidon tulum örnekleri arasında anlamlılık bağımsız örneklem t-testi (Independent Samples T-test) $(p<0,05)$ ile ve değişkenler arasındaki ilişki Pearson korelasyonu ile belirlenmiştir. 


\section{Bulgular ve Tartışma}

Çeşitli araştırıcıların daha önce Tulum peyniri üzerine yaptıkları çalışmalardaki fiziksel ve kimyasal sonuçları Çizelge 1'de, deri Tulum peynir örneklerinin fiziksel ve kimyasal analiz sonuçları Çizelge 2'de, plastik bidon peynir örneklerinin fiziksel ve kimyasal analiz sonuçları Çizelge 3'de verilmiştir.

Çizelge 1. Tulum peyniri üzerine yapılan önceki analiz sonuçları Table 1. Previous analysis results on Tulum cheese

\begin{tabular}{|c|c|c|c|c|c|c|c|c|c|}
\hline $\begin{array}{c}\text { Toplam } \\
\text { Kuru } \\
\text { madde } \\
(\%)\end{array}$ & $\begin{array}{l}\text { Yăg } \\
\text { (\%) }\end{array}$ & $\begin{array}{c}\text { Kuru } \\
\text { maddede } \\
\text { Yağ }(\%)\end{array}$ & $\begin{array}{l}\text { Protein } \\
\text { (\%) }\end{array}$ & $\begin{array}{l}\text { Tuz } \\
\text { (\%) }\end{array}$ & $\begin{array}{c}\text { Kuru } \\
\text { maddede } \\
\text { Tuz (\%) }\end{array}$ & $\begin{array}{l}\text { Kül } \\
\text { (\%) }\end{array}$ & $\begin{array}{c}\text { Asitlik } \\
\text { (\% } \\
\text { Laktik } \\
\text { Asit) }\end{array}$ & pH & Kaynak \\
\hline \multicolumn{10}{|c|}{ Deri Tulum } \\
\hline 67.21 & 34.96 & 55.73 & 21.54 & 4.66 & 7.27 & 5.50 & 1.66 & - & (Akyüz, 1981) \\
\hline $\begin{array}{l}46.00- \\
67.40\end{array}$ & - & $\begin{array}{l}9.29- \\
57.61\end{array}$ & - & - & $\begin{array}{l}3.85- \\
12.46\end{array}$ & $\begin{array}{l}1.25- \\
5.74\end{array}$ & $\begin{array}{l}0.14- \\
1.58\end{array}$ & $\begin{array}{l}4.39- \\
5.69\end{array}$ & (Çalım, 2007) \\
\hline 68.84 & 35.61 & 51.76 & 26.41 & 5.12 & 7.43 & 6.38 & 0.20 & 5.00 & $\begin{array}{l}\text { (Rençber ve Çelik, } \\
\text { 2021) }\end{array}$ \\
\hline $\begin{array}{l}60.88- \\
70.19 \\
\end{array}$ & $\begin{array}{l}34.17- \\
38.75 \\
\end{array}$ & $\begin{array}{l}55.18- \\
56.04 \\
\end{array}$ & $\begin{array}{l}24.20- \\
26.99 \\
\end{array}$ & - & $\begin{array}{l}5.64- \\
8.92 \\
\end{array}$ & - & - & - & $\begin{array}{l}\text { (Tekin ve Güler, } \\
\text { 2019) }\end{array}$ \\
\hline \multicolumn{10}{|c|}{ Plastik bidon } \\
\hline $\begin{array}{l}60.78- \\
62.13\end{array}$ & - & $\begin{array}{l}56.97- \\
57.94\end{array}$ & $\begin{array}{l}21.00- \\
21.14\end{array}$ & $\begin{array}{l}2.64- \\
3.11\end{array}$ & $\begin{array}{l}4.34- \\
5.01\end{array}$ & $\begin{array}{l}3.80- \\
4.08\end{array}$ & $\begin{array}{l}0.85- \\
1.05\end{array}$ & $\begin{array}{l}4.69- \\
5.02\end{array}$ & $\begin{array}{l}\text { (Çakır ve } \\
\text { Çakmakçı, 2018) }\end{array}$ \\
\hline $\begin{array}{l}44.80- \\
77.60 \\
\end{array}$ & - & $\begin{array}{l}10.78- \\
54.69 \\
\end{array}$ & - & - & $\begin{array}{l}3.24- \\
12.01 \\
\end{array}$ & $\begin{array}{l}2.26- \\
8.10\end{array}$ & $\begin{array}{l}0.25- \\
1.35\end{array}$ & $\begin{array}{l}4.34- \\
6.24\end{array}$ & (Çalım, 2007) \\
\hline $\begin{array}{l}42.70- \\
51.63\end{array}$ & $\begin{array}{l}19.50- \\
23.25\end{array}$ & - & $\begin{array}{l}16.07- \\
20.78\end{array}$ & $\begin{array}{l}3.47- \\
4.16 \\
\end{array}$ & - & - & $\begin{array}{l}0.14- \\
0.46\end{array}$ & $\begin{array}{l}4.54- \\
6.10\end{array}$ & $\begin{array}{l}\text { (Demirtaş ve } \\
\text { Coşkun, 2018) }\end{array}$ \\
\hline 60.05 & 33.38 & 55.60 & 22.39 & 2.96 & 4.97 & 3.77 & 0.20 & 5.20 & $\begin{array}{l}\text { (Rençber ve Çelik, } \\
\text { 2021) }\end{array}$ \\
\hline $\begin{array}{l}60.30- \\
61.14 \\
\end{array}$ & $\begin{array}{l}33.75- \\
34.17 \\
\end{array}$ & $\begin{array}{l}55.69- \\
56.10 \\
\end{array}$ & $\begin{array}{l}22.54- \\
24.20 \\
\end{array}$ & - & $\begin{array}{l}4.94- \\
5.64 \\
\end{array}$ & - & - & - & $\begin{array}{l}\text { (Tekin ve Güler, } \\
\text { 2019) }\end{array}$ \\
\hline \multicolumn{10}{|c|}{ Ambalaj materyali belli olmayanlar } \\
\hline $\begin{array}{l}53.72- \\
67.27\end{array}$ & $\begin{array}{l}12.03- \\
35.20\end{array}$ & - & $\begin{array}{l}15.78- \\
28.84\end{array}$ & $\begin{array}{l}1.52- \\
6.32\end{array}$ & - & $\begin{array}{l}1.90- \\
7.92\end{array}$ & $\begin{array}{l}0.37- \\
1.93\end{array}$ & $\begin{array}{l}4.78- \\
5.66\end{array}$ & $\begin{array}{l}\text { (Adigüzel ve ark., } \\
\text { 2009) }\end{array}$ \\
\hline $\begin{array}{l}59.10- \\
78.70\end{array}$ & $\begin{array}{l}40.00- \\
45.50\end{array}$ & - & - & $\begin{array}{l}3.74- \\
4.91\end{array}$ & - & $\begin{array}{l}4.57- \\
6.92\end{array}$ & $\begin{array}{l}0.18- \\
0.62\end{array}$ & $\begin{array}{l}4.30- \\
5.10\end{array}$ & $\begin{array}{l}\text { (Demir ve ark., } \\
\text { 2017) }\end{array}$ \\
\hline $\begin{array}{l}61.91- \\
70.34\end{array}$ & $\begin{array}{l}17.83- \\
22.83\end{array}$ & $\begin{array}{l}28.80- \\
32.85\end{array}$ & $\begin{array}{l}20.81- \\
22.09\end{array}$ & $\begin{array}{l}3.04- \\
4.37\end{array}$ & $\begin{array}{l}4.69- \\
7.05\end{array}$ & - & $\begin{array}{l}0.44- \\
0.79\end{array}$ & - & $\begin{array}{l}\text { (Dinkçi ve ark., } \\
\text { 2012) }\end{array}$ \\
\hline $\begin{array}{l}43.64- \\
62.29\end{array}$ & $\begin{array}{l}21.00- \\
36.00\end{array}$ & $\begin{array}{l}45.10- \\
65.50\end{array}$ & $\begin{array}{l}19.24- \\
27.63\end{array}$ & $\begin{array}{l}2.42- \\
4.77\end{array}$ & $\begin{array}{l}4.35- \\
9.29\end{array}$ & - & $\begin{array}{l}0.51- \\
1.77\end{array}$ & $\begin{array}{l}4.53- \\
5.03\end{array}$ & $\begin{array}{l}\text { (Erceyes ve ark., } \\
\text { 2018) }\end{array}$ \\
\hline $\begin{array}{l}41.32- \\
77.50\end{array}$ & $\begin{array}{l}14.00- \\
37.00\end{array}$ & $\begin{array}{l}34.15- \\
61.69 \\
\end{array}$ & $\begin{array}{l}14.42- \\
27.61 \\
\end{array}$ & $\begin{array}{l}1.99- \\
7.66\end{array}$ & $\begin{array}{l}3.80- \\
11.62\end{array}$ & $\begin{array}{l}1.86- \\
8.30\end{array}$ & $\begin{array}{l}0.20- \\
4.79 \\
\end{array}$ & $\begin{array}{l}4.08- \\
5.01 \\
\end{array}$ & (Kiraz, 2018) \\
\hline $\begin{array}{l}36.06- \\
66.82\end{array}$ & $\begin{array}{l}13.00- \\
32.00\end{array}$ & $\begin{array}{l}32.40- \\
51.60\end{array}$ & - & $\begin{array}{l}1.75- \\
5.81\end{array}$ & $\begin{array}{l}2.99- \\
10.42\end{array}$ & $\begin{array}{l}3.59- \\
5.98\end{array}$ & $\begin{array}{l}0.36- \\
2.63\end{array}$ & $\begin{array}{l}4.51- \\
6.94\end{array}$ & $\begin{array}{l}\text { (Morul ve İşleyici, } \\
\text { 2012) }\end{array}$ \\
\hline $\begin{array}{l}52.42- \\
68.46\end{array}$ & $\begin{array}{l}21.00- \\
38.00\end{array}$ & $\begin{array}{l}36.27- \\
61.93 \\
\end{array}$ & $\begin{array}{l}20.18- \\
25.86\end{array}$ & $\begin{array}{l}2.57- \\
6.32\end{array}$ & $\begin{array}{l}4.27- \\
10.52\end{array}$ & $\begin{array}{l}2.81- \\
5.61\end{array}$ & $\begin{array}{l}0.83- \\
1.35\end{array}$ & - & $\begin{array}{l}\text { (Sancak ve ark., } \\
\text { 2018) }\end{array}$ \\
\hline
\end{tabular}

Daha önce yapılan Tulum peyniri çalışmalarında toplam kuru madde sonuçları \% 36.06-78.70 arasında değişmiş olup çalışma sonuçlarımız bu değerlerin arasında bulunmuştur. Kuru madde miktarı açısından minimum, maksimum ve ortalama değerler deri Tulum peynirlerinde plastik bidon Tulum peynirlerine göre daha yüksek bulunmuştur. Bu durum plastik bidonda yapılan Tulum peynirinin daha zor rutubet kaybetmesinden kaynaklanabilir. Türk Gida Kodeksi peynir tebliğinde (Anonim, 2015) kuru madde yönünden yapılan sınıflandırmada peynirlerde en az \% 55 kuru madde bulunması gerektiği belirtilmiştir. Yaptığımız çalışmada 35 deri Tulum peynir örneğinin 16 adedi bu değeri sağlarken (\% 46), 19 adedi bu kuru madde değerinden düşük bulunmuştur (\% 54). Plastik bidon Tulum peyniri açısından ise 28 örnekten 5 adedi bu değeri sağlarken (\% 18) 23 adedi bu değerin altında bulunmuştur (\% 82). Ortalama değerler incelenecek olursa deri Tulum peynir örneklerinde bu değer \% 54.47 olarak, plastik bidon Tulum peynir örneklerinde bu değer \% 47.95 olarak daha düşük bulunmuştur. Kuru madde; peynirlerde, besin değeri, kalite, dayanma niteliği, bileşim ve kıvamı önemli ölçüde etkiler. Kuru madde oranı yükseldikçe peynirlerin 
Çizelge 2. Deri Tulum peynir örneklerinin fiziksel ve kimyasal analiz sonuçları

Table 2. Physical and chemical analysis results of leather Tulum cheese samples

\begin{tabular}{lcccc}
\hline Özellikler & Minimum & Maksimum & Ortalama & Standart Sapma \\
\hline Toplam kuru madde (\%) & 41.79 & 67.21 & 54.47 & 7,51595 \\
\hline Yağ (\%) & 20.19 & 32.51 & 23.68 & 3.26224 \\
\hline Kuru maddede yă̆ (\%) & 37.38 & 48.87 & 43.61 & 2.94737 \\
\hline Protein (\%) & 20.35 & 30.14 & 22.90 & 2.68533 \\
\hline Tuz (\%) & 3.16 & 5.61 & 3.89 & 0.60299 \\
\hline Kuru maddede tuz (\%) & 6.06 & 8.43 & 7.16 & 0.60670 \\
\hline Kül (\%) & 3.76 & 6.78 & 4.91 & 0.73078 \\
\hline Asitlik (\% Laktik Asit) & 0.69 & 1.22 & 0.96 & 0.12796 \\
\hline pH & 4.37 & 6.22 & 5.41 & 0.50100 \\
\hline
\end{tabular}

Çizelge 3. Plastik bidon peynir örneklerinin fiziksel ve kimyasal analiz sonuçları Table 3. Physical and chemical analysis results of cheese samples in plastic drums

\begin{tabular}{lcccc}
\hline Özellikler & Minimum & Maksimum & Ortalama & Standart Sapma \\
\hline Toplam kuru madde (\%) & 38.71 & 60.66 & 47.95 & 6,70756 \\
\hline Yağ (\%) & 17.25 & 23.66 & 20.88 & 1.64471 \\
\hline Kuru maddede yağ (\%) & 37.72 & 49.29 & 43.93 & 3.21621 \\
\hline Protein (\%) & 16.55 & 23.31 & 20.20 & 1.81383 \\
\hline Tuz (\%) & 2.65 & 3.98 & 3.52 & 0.32157 \\
\hline Kuru maddede tuz (\%) & 6.30 & 9.48 & 7.41 & 0.80674 \\
\hline Kül (\%) & 2.88 & 5.22 & 4.28 & 0.53254 \\
\hline Asitlik (\% Laktik Asit) & 0.74 & 1.23 & 0.97 & 0.13813 \\
\hline pH & 3.82 & 5.66 & 4.89 & 0.45701 \\
\hline
\end{tabular}

besleme değeri de artar. Peynirlerin kuru madde içerikleri; ürünün yapılışı, çeşidi, olgunluk derecesi, işlendiği sütün niteliği gibi çeşitli faktörlere bağlı olarak değişmektedir.

Yağ değerleri daha önceki çalışmalarda \% 12.03-45.50 arasında bulunmuş, çalışma sonucunda bulduğumuz değerler bu değerlerin arasındadır. Yağ miktarı açısından minimum, maksimum ve ortalama değerler deri Tulum peynirlerinde plastik bidon Tulum peynirlerine göre daha yüksek bulunmuştur. Türk gıda kodeksi peynir tebliğinde (Anonim, 2015) \% 25-45 arası yarım yağlı peynir, \% 10-25 arası az yağlı peynir olarak sınıflandırılmaktadır. Yaptığımız çalışmada 35 deri Tulum peynir örneğinin 9 adedi (\% 26) yarım yağl1, 26 adedi az (\% 74) az yağlı peynir grubundadır. Plastik bidon Tulum peyniri açısından ise 28 örneğin tamamı (\% 100) az yağlı peynir grubunda yer almıştır. Yağ oranı peynir kuru maddesinin önemli kısmını teşkil eder ve onun kalitesi tadı, aroması ve besin değerini etkiler. Peynir örneklerinin yağ miktarları, kuru madde değerlerine bağlı olarak oransal olarak yüksek veya düşük çıkmıştır.

Kuru maddede yağ değeri daha önce yapılan Tulum peyniri çalışmalarında \% 9.29-65.50 arasında değişmiş olup sonuçlarımız bu değerlerin arasında belirlenmiştir. Kuru maddede yağ miktarı açısından minimum, maksimum ve ortalama değerler plastik bidon Tulum peynirlerinde deri Tulum peynirlerine göre daha yüksek bulunmuştur. Peynirlerdeki yağ oranı önemli ölçüde bileşimindeki nem miktarına bağlı olarak değişmektedir. Bu nedenle yağın kuru madde içindeki payının da ayrıca belirtilmesi gerekmektedir. Peynirin sınıflandırılmasında kullanıldığından peynirlerin yağ içeriği tüm kitlede değil de kuru maddeye oranlanarak ifade edilmektedir.

Toplam protein değeri önceki çalışmalarda \% 14.42-28.84 arasında belirlenmiş ve çalışma sonucunda bulduğumuz deri Tulum örneklerine ait en yüksek protein değeri diğer araştırıcıların belirlediği en yüksek protein değerinden daha fazla, plastik bidon Tulum peynirine ait protein değerleri bu değerlerin arasında bulunmuştur. Protein, peynirin besin değerini arttıran önemli bir bileşendir. Tulum peynir örneklerinin protein miktarlarının farklılık göstermesi, kullanılan sütlerin bileşiminin farklı olması, sütün farklı hayvan türlerinden elde edilmiş olması ve üretim tekniğinin standart olmamasından kaynaklanabilir.

Tuz miktarı önceki çalışmalarda \% 1.52-7.66 arasında belirlenmiş olup çalışmada elde ettiğimiz bulgular bu değerler arasındadır. Tuz miktarı açısından minimum, maksimum ve ortalama değerler plastik bidon Tulum peynirlerinde deri Tulum peynirlerine göre daha yüksek bulunmuştur. Türk gıda kodeksi peynir tebliğinde (Anonim, 2015) tuz yönünden yapılan sınıflandırmada peynirlerde en fazla $\% 5$ tuz bulunabileceği belirtilmiştir. Yaptığımız çalışmada 35 deri Tulum peynir örneğinin 3 adedi (\% 9), bu değerin üzerinde bulunmuş, 32 adedi (\% 91) ve plastik 
bidon Tulum peynirlerinin tamamı olan 28 adedi $(\%$ 100) bu değerin altında bulunmuştur. Tuz, dayanıklılığı artırmak ve peynire lezzet vermek için ona sonradan katılır. Ayrıca peynirlerde olgunlaşma, kıvam ve randıman üzerine de etkisi vardır. Özellikle diğer araştırıcıların yaptıkları çalışmalarda tuz miktarları büyük değişkenlik göstermektedir. $\mathrm{Bu}$ durum Tulum peyniri üretiminde katılan tuzun üreticilerin tecrübe ve alışkanlılarına göre değişmesinin bir sonucu olabilir.

Kuru maddede tuz değeri önceki araştırmalarda \% 2.99-12.46 arasında belirlenmiş olup çalışmada elde ettiğimiz bulgular bu sonuçların arasında belirlenen değerlerdedir. Kuru maddede açısından tuz miktarı minimum, maksimum ve ortalama değerler plastik bidon Tulum peynirlerinde deri Tulum peynirlerine göre daha yüksek bulunmuştur.

Kül miktarı önceki çalışmalarda \% 1.25-8.30 arasında bulunmuş elde ettiğimiz bulguların bu değerler arasında olduğu görülmüştür. Kül miktarı açısından minimum, maksimum ve ortalama değerler deri Tulum peynirlerinde plastik bidon Tulum peynirlerine göre daha yüksek bulunmuştur. Süt ve tuzdan gelen mineral maddelerin tamamı bütün kül oranını oluşturmaktadır. Örneklerin kül miktarlarında ortaya çıkan farklılıklar içerdikleri tuz miktarlarından kaynaklanabilmektedir.

Asitlik tayini sonuçları önceki çalışmalarda \% 0.14-4.79 arasında değişmiş, elde ettiğimiz bulgular bu değerlerin arasındadır. Asitlik açısından minimum, maksimum ve ortalama değerler plastik bidon Tulum peynirlerinde deri Tulum peynirlerine göre daha yüksek bulunmuştur. Peynirlerde asitlik, önemli ölçüde peynirin işlendiği sütten gelen laktozun mikroorganizmalar tarafından laktik aside çevrilmesiyle oluşmaktadır. Olgunlaşma sırasında biyokimyasal olaylar gerçekleşmesinde ortam asitliğinin çok büyük etkisi olduğundan peynirin kalitesi üzerine asitlik önemli ölçüde etkilidir. Peynirlerde asitlik; kullanılan starter bakterilerine, ürünün muhafaza koşullarına, nem içeriğine, laktoz ve tuz miktarına bağlı olarak değişebilmektedir.

pH değeri daha önce yapılan çalışmalarda 4.08-6.94 arasında belirlenmiş, elde ettiğimiz bulguların bu sonuçların arasında olduğu görülmüştür. $\mathrm{pH}$ açısından minimum, maksimum ve ortalama değerler deri Tulum peynirlerinde plastik bidon Tulum peynirlerine göre daha yüksek bulunmuştur. Olgunlaşma sırasında bazik karakterli proteolitik parçalanma ürünleri ile mayalar tarafından laktik asidin etil alkole dönüştürülmesi, peynirde $\mathrm{pH}$ değerinin yükselmesine neden olabilmektedir.

İstatistik sonuçlarına göre deri Tulum ve plastik kaptaki Tulumlarda yapılan kimyasal analizlerden kuru maddede yağ, kuru maddede tuz, asitlik oranı arasında bir fark bulunmazken toplam kuru madde $(\mathrm{p} \leq 0,01)$, yă $(\mathrm{p}<0,01)$, protein $(\mathrm{p}<0,01)$, tuz $(\mathrm{p}<0,01)$, kül $(\mathrm{p}<0,01)$ ve $\mathrm{pH}(\mathrm{p}<0,01)$ 'da ürünler arasında önemli ölçüde fark tespit edilmiştir. İstatistiki olarak mikrobiyolojik analizler arasında deri Tulum ile plastik bidon Tulumları arasında fark belirlenmemiş olup benzer sonuçlar elde edilmiştir ( $\mathrm{p}>0.05$ ).

Çalışma sonuçları genel olarak değerlendirildiğinde diğer araştırıcıların kontrollü şartlarda ürettikleri Tulum peynirlerinde fiziksel ve kimyasal analiz sonuçlarının hazırlama koşullarına bağlı olarak yakın değerler gösterdiği belirlenmiştir. Ancak piyasadan alınıp analize tabi tutulan Tulum peyniri örneklerinde bu değerler çok fazla değişken aralıkta olduğu görülmüştür. Bu da Tulum peyniri üretiminde standart bir hammadde kullanılmamasının ve yine standart bir yöntem uygulanmamasının bir sonucu olarak belirtilebilir.

Çeşitli araştırıcıların daha önce Tulum peyniri üzerine yaptıkları çalışmalardaki mikrobiyolojik analiz sonuçları Çizelge 4'de, deri Tulum peynir örneklerinin mikrobiyolojik analiz sonuçları Çizelge 5'de, plastik bidon peynir örneklerinin mikrobiyolojik analiz sonuçları Çizelge 6'da verilmiştir.

Daha önce yapılan Tulum peyniri çalışmalarında toplam mezofilik aerob bakteri sayısı 2.56-9.89 $\left(\log _{10} \mathrm{kob} / \mathrm{g}\right)$ olarak belirlenmiş, elde ettiğimiz bulguların bu sonuçların arasında olduğu görülmüştür. Toplam mezofilik aerob bakteri sayısı açısından minimum, maksimum ve ortalama değerler deri Tulum peynirlerinde plastik bidon Tulum peynirlerine göre daha yüksek bulunmuştur. Tulum peynirlerinde toplam mezofilik aerob mikroorganizma sayısının yüksek olması, üretimde çiğ süt kullanılmasının bir sonucu olabilir.

Daha önce yapılan Tulum peyniri çalışmalarında laktik asit bakteri sayısı 7.89-8.10 $\left(\log _{10} \mathrm{kob} / \mathrm{g}\right)$ olarak belirlenmiş, elde ettiğimiz bulguların bu sonuçlardan daha düşük olduğu görülmüştür. Toplam laktik asit bakteri sayısı açısından minimum ve maksimum değerler deri Tulum peynirlerinde plastik bidon Tulum peynirlerine göre daha yüksek, ortalama değer ise aynı bulunmuştur. Laktik asit bakteri grubunda yer alan ve ürünlerin kendine has lezzet, aroma ve dayanma süresi üzerine etki eden önemli bir bakteri grubu da Lactobacillus-LeuconostocPediococcus mikroorganizmalarıdır (Demir ve ark., 2017). Bu grup mikroorganizmaların yüksek seviyelerde olması sütten gelen laktik asit bakteri sayısının fazla olmasına, peynirin yapım aşamasında havalandırılması esnasında havadan bu mikroorganizmalarla bulaşma düzeyinden kaynaklanabilir.

Daha önce yapılan Tulum peyniri çalışmalarında maya-küf sayısı 0-8.48 (log10 kob/g) olarak belirlenmiş, elde ettiğimiz bulguların bu sonuçların arasında olduğu görülmüştür. Maya-küf sayısı açısından minimum, maksimum ve ortalama değerler deri Tulum peynirlerinde plastik bidon Tulum peynirlerine göre daha yüksek bulunmuştur. Mayaküfler tüm gıda maddelerinin dayanma süresi, kalitesi ve lezzetine üzerine etkili olan mikroorganizma gruplarındandırlar. Özellikle peynirlerde sayılarının yüksek çıkması hammadde ve üretimde çok fazla bulaşmanın bir sonucu olabilir. 
Daha önce yapılan Tulum peyniri çalışmalarında koliform bakteri sayısı 0-7.34 ( $\left.\log _{10} \mathrm{kob} / \mathrm{g}\right)$ olarak belirlenmiş, elde ettiğimiz bulguların bu sonuçların arasında olduğu görülmüştür. Koliform bakteri sayısı açısından minimum ve maksimum değerler deri Tulum peynirlerinde plastik bidon Tulum peynirlerine göre daha yüksek, ortalama değer Çizelge 4. Tulum peyniri üzerine yapılan önceki mikrobiyolojik analiz sonuçları $\left(\log _{10} \mathrm{kob} / \mathrm{g}\right)^{*}$

Table 4. Results of previous microbiological analysis on Tulum cheese $\left(\log _{10} \mathrm{cfu} / \mathrm{g}\right) *$

\begin{tabular}{|c|c|c|c|c|c|c|c|c|c|c|c|c|}
\hline TMABS & $\begin{array}{l}\text { LB } \\
\mathrm{S} \\
\end{array}$ & $\begin{array}{l}\text { MK } \\
\mathrm{S} \\
\end{array}$ & KS & $\mathrm{ES}$ & EBS & STS & PS & PB & LB & SV & LV & Kaynak \\
\hline \multicolumn{13}{|c|}{ Deri Tulum } \\
\hline $\begin{array}{l}6.83- \\
9.03\end{array}$ & - & $\begin{array}{l}0- \\
7.26\end{array}$ & $\begin{array}{l}0- \\
7.14\end{array}$ & $\begin{array}{l}0- \\
6.61\end{array}$ & - & $\begin{array}{l}2.18- \\
7.41\end{array}$ & - & - & - & $* *$ & - & $\begin{array}{l}\text { (Çalım, } \\
\text { 2007) }\end{array}$ \\
\hline- & 8.10 & 5.11 & 4.57 & 2.02 & - & - & - & - & - & - & - & $\begin{array}{l}\text { (Rençber ve } \\
\text { Çelik, 2021) }\end{array}$ \\
\hline \multicolumn{13}{|c|}{ Plastik bidon } \\
\hline $\begin{array}{l}7.19- \\
8.09\end{array}$ & - & $\begin{array}{l}4.13- \\
6.14\end{array}$ & $\begin{array}{l}2.15- \\
3.73\end{array}$ & - & - & $\begin{array}{l}2 \text { den } \\
\text { fazla }\end{array}$ & - & - & - & - & - & $\begin{array}{l}\text { (Çakır ve } \\
\text { Çakmakçı, } \\
\text { 2018) }\end{array}$ \\
\hline $\begin{array}{l}6.54- \\
8.98 \\
\end{array}$ & - & $\begin{array}{l}0- \\
7.54 \\
\end{array}$ & $\begin{array}{l}0- \\
7.34 \\
\end{array}$ & $\begin{array}{l}0- \\
6.99\end{array}$ & - & $0-7.08$ & - & - & - & $* *$ & - & $\begin{array}{l}\text { (Çalım, } \\
\text { 2007) }\end{array}$ \\
\hline $\begin{array}{l}2.56- \\
7.08\end{array}$ & - & $\begin{array}{l}1.66- \\
3.68\end{array}$ & $\begin{array}{l}0- \\
3.30\end{array}$ & - & - & $\begin{array}{l}1.00- \\
5.38\end{array}$ & - & - & - & - & - & $\begin{array}{l}\text { (Demirtaş } \\
\text { ve Coşkun, } \\
\text { 2018) }\end{array}$ \\
\hline - & 7.89 & 5.39 & 3.27 & 1.05 & - & - & - & - & - & - & - & $\begin{array}{l}\text { (Rençber ve } \\
\text { Çelik, 2021) }\end{array}$ \\
\hline \multicolumn{13}{|c|}{ Ambalaj materyali belli olmayanlar } \\
\hline $\begin{array}{l}5.02- \\
9.83\end{array}$ & - & $\begin{array}{l}<2- \\
7.82\end{array}$ & - & $\begin{array}{l}<2- \\
5.13\end{array}$ & $\begin{array}{l}<2- \\
7.27\end{array}$ & $\begin{array}{l}<2- \\
4.93\end{array}$ & - & - & - & $* *$ & $* *$ & $\begin{array}{l}\text { (Adıgüzel } \\
\text { ve ark., } \\
\text { 2009) }\end{array}$ \\
\hline & & & & & & & & & & & $* * *$ & $\begin{array}{l}\text { (Azak ve } \\
\text { ark., 2012) }\end{array}$ \\
\hline $\begin{array}{l}8.05- \\
9.89 \\
\end{array}$ & - & - & $\begin{array}{l}2.05- \\
4.34 \\
\end{array}$ & & - & - & - & $\begin{array}{l}5.30- \\
8.65 \\
\end{array}$ & $\begin{array}{l}5.50- \\
8.06 \\
\end{array}$ & - & - & $\begin{array}{l}\text { (Demir ve } \\
\text { ark., 2017) }\end{array}$ \\
\hline $\begin{array}{l}3.12- \\
8.03\end{array}$ & - & $\begin{array}{l}1.00- \\
7.34\end{array}$ & $\begin{array}{l}1.00- \\
5.98\end{array}$ & $\begin{array}{l}1.00- \\
2.65\end{array}$ & - & $\begin{array}{l}1.00- \\
2.05 \\
\end{array}$ & - & - & - & - & - & $\begin{array}{l}\text { (Demir ve } \\
\text { ark., 2018) }\end{array}$ \\
\hline $\begin{array}{l}6.74- \\
7.26 \\
\end{array}$ & - & $\begin{array}{l}5.54- \\
7.26 \\
\end{array}$ & - & - & - & - & - & - & - & - & - & $\begin{array}{l}\text { (Dinkçi ve } \\
\text { ark., 2012) }\end{array}$ \\
\hline- & - & $\begin{array}{l}3.79- \\
7.76 \\
\end{array}$ & $\begin{array}{l}<10- \\
5.05\end{array}$ & - & - & - & - & - & - & - & - & $\begin{array}{l}\text { (Kiraz, } \\
\text { 2018) }\end{array}$ \\
\hline $\begin{array}{l}3.00- \\
9.02\end{array}$ & - & $\begin{array}{l}2.70- \\
8.48\end{array}$ & $\begin{array}{l}1.00- \\
5.46\end{array}$ & $\begin{array}{l}2.00- \\
4.75\end{array}$ & $\begin{array}{l}1.00- \\
5.75\end{array}$ & $\begin{array}{l}2.00- \\
8.00\end{array}$ & $\begin{array}{l}2.00- \\
6.08\end{array}$ & - & - & - & - & $\begin{array}{l}\text { (Morul ve } \\
\text { İşleyici, } \\
\text { 2012) } \\
\end{array}$ \\
\hline - & - & - & - & - & - & - & $\begin{array}{l}<2- \\
4.64\end{array}$ & - & - & - & - & $\begin{array}{l}\text { (Tomar ve } \\
\text { ark., 2018) }\end{array}$ \\
\hline
\end{tabular}

*TMABS, toplam mezofilik aerob bakteri sayıs1; LBS, laktik asit bakteri sayısı; MKS, maya-küf sayıs1; KS, koliform bakteri sayıs1; ES, E.coli sayıs1; EBS, Enterobacteriaceae spp. sayıs1; STS, Staphylococcus aureus sayıs1; PS, Pseudomonas spp. sayıs1; PB, proteolitik bakteri sayısi; LB, lipolitik bakteri sayısı; SV, Salmonella spp. varlığı; LV, Listeria spp. varlığını belirtmektedir.

** Tespit edilemedi

***\%\% 3 'ünde tespit edilmiş

ise plastik bidon Tulum peynirlerinde deri Tulum peynirlerine göre daha yüksek bulunmuştur. Koliform grubu bakterilerin gıda maddelerinde yüksek sayılarda bulunması sanitasyon işlemlerinin ve ürüne uygulanan 1sı işlemlerinin yetersiz olduğunun ya da işlem sonrası bulaşmanın göstergesidir.

Daha önce yapılan Tulum peyniri çalışmalarında E.coli sayısı $0-6.99\left(\log _{10} \mathrm{kob} / \mathrm{g}\right)$ olarak belirlenmiş, elde ettiğimiz bulguların bu sonuçların arasında olduğu görülmüştür. E.coli sayısı açısından minimum ve maksimum değerler deri Tulum peynirlerinde plastik bidon Tulum peynirlerine göre daha yüksek, ortalama değer ise plastik bidon Tulum peynirlerinde deri Tulum peynirlerine göre daha yüksek bulunmuştur. E.coli gıda zehirlenmelerine neden olabilen ve hijyenik kalitenin bir göstergesi olarak kabul edilen bir bakteridir.

Daha önce yapılan Tulum peyniri çalışmalarında Enterobacteriaceae spp. sayısı 1-7.27 (log 10 kob/g) olarak belirlenmiş, elde ettiğimiz bulguların bu sonuçların arasında olduğu görülmüştür. Enterobacteriaceae spp. sayısı açısından maksimum ve ortalama değerler deri Tulum peynirlerinde plastik bidon Tulum peynirlerine göre daha yüksek, minimum değer ise aynı bulunmuştur. Enterobacteriaceae sayısının peynir yapımı veya depolama sırasında gerçekleşen bir bulaşmadan kaynaklandığı düşünülebilir. 
Daha önce yapılan Tulum peyniri çalışmalarında Staphylococcus aureus sayısı 0-8.00 ( $\left.\log _{10} \mathrm{kob} / \mathrm{g}\right)$ olarak belirlenmiş, elde ettiğimiz bulguların bu sonuçların arasında olduğu görülmüştür. Staphylococcus aureus sayısı Çizelge 5. Deri Tulum peynir örneklerinin mikrobiyolojik analiz sonuçları $\left(\log _{10} \mathrm{kob} / \mathrm{g}\right) *$

Table 5. Microbiological analysis results of leather Tulum cheese samples $\left(\log _{10} \mathrm{cfu} / \mathrm{g}\right) *$

\begin{tabular}{lllll}
\hline Özellikler & Minimum & Maksimum & Ortalama & Standart Sapma \\
\hline TMABS & 6.83 & 7.64 & 7.15 & 0.24002 \\
\hline LBS & 5.78 & 7.28 & 6.54 & 0.48888 \\
\hline MKS & 3.82 & 6.82 & 5.35 & 0.76110 \\
\hline KS & 1.92 & 5.44 & 4.15 & 0.92829 \\
\hline ES & 1.45 & 5.22 & 3.25 & 0.89705 \\
\hline EBS & $<10$ & 3.12 & 2.14 & 0.73130 \\
\hline STS & 2.36 & 5.76 & 4.36 & 0.94024 \\
\hline PS & 2.25 & 5.40 & 4.04 & 0.90319 \\
\hline PB & 1.53 & 4.27 & 3.04 & 0.85920 \\
\hline LB & 2.13 & 4.92 & 3.82 & 0.73308 \\
\hline SV & - & - & - & - \\
\hline LV & - & - & - & - \\
\hline
\end{tabular}

*TMABS, toplam mezofilik aerob bakteri sayıs1; LBS, laktik asit bakteri sayısı; MKS, maya-küf sayıs1; KS, koliform bakteri sayıs1; ES, E.coli sayıs1; EBS, Enterobacteriaceae spp. sayıs1; STS, Staphylococcus aureus sayıs1; PS, Pseudomonas spp. sayıs1; PB, proteolitik bakteri sayıs1; LB, lipolitik bakteri sayısı; SV, Salmonella spp. varlığı; LV, Listeria spp. varlığını belirtmektedir.

Çizelge 6. Plastik bidon peynir örneklerinin mikrobiyolojik analiz sonuçları $\left(\log _{10} \mathrm{kob} / \mathrm{g}\right)^{*}$ Table 6. Microbiological analysis results of cheese samples in plastic drums $\left(\log _{10} \mathrm{cfu} / \mathrm{g}\right) *$

\begin{tabular}{lcccc}
\hline Özellikler & Minimum & Maksimum & Ortalama & Standart Sapma \\
\hline TMABS & 6.72 & 7.52 & 7.10 & 0.26058 \\
\hline LBS & 5.62 & 7.12 & 6.54 & 0.52890 \\
\hline MKS & 3.75 & 6.54 & 5.47 & 0.85448 \\
\hline KS & 1.74 & 5.33 & 4.31 & 0.99574 \\
\hline ES & 1.23 & 4.96 & 3.34 & 0.94232 \\
\hline EBS & $<10$ & 2.81 & 1.83 & 0.78149 \\
\hline STS & 2.36 & 5.28 & 4.10 & 0.86619 \\
\hline PS & 2.03 & 4.76 & 3.60 & 0.74045 \\
\hline PB & 1.26 & 3.84 & 2.51 & 0.85365 \\
\hline LB & 1.82 & 4.67 & 3.33 & 0.89986 \\
\hline SV & - & - & - & - \\
\hline LV & - & - & - & -
\end{tabular}

*TMABS, toplam mezofilik aerob bakteri sayısı; LBS, laktik asit bakteri sayısı; MKS, maya-küf sayısı; KS, koliform bakteri sayısı; ES, E.coli sayıs1; EBS, Enterobacteriaceae spp. sayıs1; STS, Staphylococcus aureus sayıs1; PS, Pseudomonas spp. sayıs1; PB, proteolitik bakteri sayısı; LB, lipolitik bakteri sayısı; SV, Salmonella spp. varlığı; LV, Listeria spp. varlığını belirtmektedir.

açısından maksimum ve ortalama değerler deri Tulum peynirlerinde plastik bidon Tulum peynirlerine göre daha yüksek, minimum değer ise aynı bulunmuştur. Bazı Staphylococcus suşlarının gıdalarda zehirlenmelere neden olduğu bilinmektedir. Bu nedenle özellikle Staphylococcus aureus'un gidalarda bulunmaması gerekmektedir. Özellikle üretimde çalışanların hijyenik kurallara uymaması son üründe Staphylococcus aureus bulunmasının en büyük nedenidir.

Daha önce yapılan Tulum peyniri çalışmalarında Pseudomonas spp. sayısı <2-6.08 $\left(\log _{10} \mathrm{kob} / \mathrm{g}\right)$ olarak belirlenmiş, elde ettiğimiz bulguların bu sonuçların arasında olduğu görülmüşür. Pseudomonas spp. sayısı açısından minimum, maksimum ve ortalama değerler deri Tulum peynirlerinde plastik bidon Tulum peynirlerine göre daha yüksek bulunmuştur. Peynirlerde meydana gelen en önemli tat kusurları arasında acılık ve ransidite öncelikli sırayı almaktadır ve bu kusurların birçoğuna 1sıya dirençli lipaz ve proteaz üreten Pseudomonas'lar sebep olmaktadır (Yerlikaya, 2018).

Daha önce yapılan Tulum peyniri çalışmalarında proteolitik bakteri sayıs1 5.30-8.65 $\left(\log _{10} \mathrm{kob} / \mathrm{g}\right)$ olarak belirlenmiş, elde ettiğimiz bulguların bu sonuçların arasında olduğu görülmüştür. Proteolitik bakteri sayısı açısından minimum, maksimum ve ortalama değerler deri Tulum peynirlerinde plastik bidon Tulum peynirlerine göre daha yüksek bulunmuştur. Proteolitik mikroorganizmalar özellikle süt ürünlerinde proteini parçalayarak istenmeyen tat ve kokulara neden olurlar. 
Daha önce yapılan Tulum peyniri çalışmalarında lipolitik bakteri sayısı 5.50-8.06 $\left(\log _{10} \mathrm{kob} / \mathrm{g}\right)$ olarak belirlenmiş, elde ettiğimiz bulguların bu sonuçların arasında olduğu görülmüştür. Lipolitik bakteri sayısı açısından minimum, maksimum ve ortalama değerler deri Tulum peynirlerinde plastik bidon Tulum peynirlerine göre daha yüksek bulunmuştur. Lipolitik bakteri sayımı, lipoliz olayında etkili olan ve lipolitik aktiviteye sahip mikroorganizmaların varlığını belirlemek amacıly yapılmaktadır.

Analize alınan deri Tulum peynir örneklerinde yapılan Salmonella spp. varlığı ve Listeria spp. varlığ analizlerinde hiçbir örnekte Salmonella spp. ve Listeria spp. tespit edilmemiştir. Daha önce yapılan Tulum peyniri çalışmalarında Salmonella spp. tespit edilememiştir (Adıgüzel ve ark., 2009; Çalım, 2007). Listeria spp. ise bir çalışmada tespit edilmezken (Adıgüzel ve ark., 2009) bir çalışmada örneklerin \% 3'ünde tespit edilmiştir (Azak ve ark., 2012). Salmonella ve Listeria en çok hayvansal ürünlerde ve bunlar arasında peynirlerde bulunmakta ve insan sağlığı açısından büyük önem taşımaktadır. Türk gıda kodeksi mikrobiyolojik kriterler yönetmeliğinde peynirlerde kesinlikle Salmonella spp. ve Listeria monocytogenes bulunmayacağı belirtilmektedir (Anonim, 2011).

Deri Tulum örneklerinde kuru maddede yağ içeriği ile Enterobacteriaceae spp. hariç diğer mikrobiyolojik analizler arasında orta seviyeye yakın düzeyde ters bir ilişki olduğu tespit edilmiştir $(-0,542<r<-0,226)$. Kuru maddede tuz oranında ise Staphylococcus aureus $(\mathrm{r}=-0,433)$ ve Pseudomonas spp. sayısı $(\mathrm{r}=-0,343)$ ile ters bir ilişki belirlenmiş olup diğer analizler arasında anlamlı bir ilişki gözlenmemiştir ( $p>0,05)$. Deri Tulum peyniri için mikrobiyolojik analiz sonuçları ile asitlik düzeyi arasında yüksek düzeyde ters orantılı bir ilişki olduğu tespit edilmiş olup $(-0,820<\mathrm{r}<-0,579)$ bu durum $\mathrm{pH}$ için doğru orantılıdır $(0,369<\mathrm{r}<0,903)$. $\mathrm{pH}$ için bu doğrusal oran en yüksek maya-küf sayısında belirlenmiştir $(\mathrm{r}=0,903)$

Yağ oranı ile laktik asit bakterileri $(\mathrm{r}=0,517)$, maya-küf sayıs1 $(\mathrm{r}=0,399)$, koliform bakteri sayısı $(\mathrm{r}=0,393)$, Staphylococcus aureus sayısı $(\mathrm{r}=0,382)$ ve lipolitik bakteri sayısı $(\mathrm{r}=0,384)$ arasında orta düzeyde doğru orantılı bir ilişki bulunurken diğer mikrobiyolojik analizler arasında anlamlı bir ilişki bulunmamıştır. Laktik asit bakterileri ile protein oranı arasında orta düzeyde bir korelasyon gözlenmiştir $(r=0,441)$. Tuz miktarı ile laktik asit bakteri sayısı $(\mathrm{r}=0,495)$, maya-küf sayıs1 $(\mathrm{r}=0,571)$, koliform bakteri sayıs1 $(\mathrm{r}=0,473)$, E.coli sayıs1 $(\mathrm{r}=0,432)$, proteolitik bakteri sayısı $(\mathrm{r}=0,401)$ arasında orta düzeyde bir ilişki olduğu belirlenmiştir. Asitlik miktarı ile Enterobacteriaceae spp. sayısı ve maya-küf sayısında düşük olmak üzere diğer tüm mikrobiyolojik analizlerde yüksek düzeyde bir ters orantılı ilişki mevcuttur $(-0,833<\mathrm{r}<-0,574)$. $\mathrm{pH}$ 'da ise bu durum doğru orantılı bir şekilde olmakla birlikte maya-küf sayısında çok yüksek oranda ilişkilidir $(\mathrm{r}=0,947)$. $\mathrm{pH}$ ile maya-küf sayısı arasında yüksek düzeyde $(\mathrm{r}=0,77)$ pozitif yönde bir korelasyon gözlenirken diğer mikrobiyolojik analizler için orta düzeyde pozitif bir ilişki tespit edilmiştir. Asitlikte ise mikrobiyolojik analizler arasında negatif ilişki söz konusudur. Asitliğin en fazla ilişkide olduğu analizler sirasi ile toplam mezofilik aerob bakteri sayıs $(\mathrm{r}=-0,856)$, koliform bakteri sayıs1 $(\mathrm{r}=-0,796)$, Staphylococcus aureus sayısı $(\mathrm{r}=-0,759)$, E.coli sayısı $(\mathrm{r}=-0,754)$, lipolitik bakteri sayısı $(\mathrm{r}=-0,744)$ iken diğer analizlerde orta düzeyde bir ilişki ( $\mathrm{r}-0,480$ ile $-0,6898$ arası) mevcuttur. Tuz miktarı ile mikrobiyolojik analizler arasında ilişki saptanmamıştır $(\mathrm{p}>0,05)$. Kuru maddede yă oranı ile Staphylococcus aureus $(\mathrm{r}=-0,296)$ ve Pseudomonas spp. sayısı $(\mathrm{r}=0,0257)$ arasında düşükte olsa negatif bir ilişki söz konusu iken diğer mikrobiyolojik analizlerde anlamlı bir ilişki gözlenmemiştir ( $\mathrm{p}>0,05)$.

Mikroorganizma sayısının yüksek çıkması çiğ süt kullanımı ve hijyenik olmayan üretim süreçlerinden kaynaklanıyor olabilir. Elde edilen sonuçlar değerlendirildiği zaman bazı bakteri (E.coli, Staphylococcus aureus gibi) sayılarının insan sağlığı açısından riskli olabilecek seviyelerde oldukları belirlenmiştir. Bundan dolayı bu ürünlerin yapımında kullanılan sütlerin uygun derecelerde ve uygun sürelerde pastörize edilmesi, yapımında starter kültür kullanılması ve üretimde gıda güvenliği sistemlerinin uygulanması önerilebilir.

Deri Tulum peynir örneklerinin duyusal analiz sonuçları Çizelge 7'de ve plastik bidon peynir örneklerinin duyusal analiz sonuçları Çizelge 8 'de verilmiştir.

Çizelge 7. Deri Tulum peynir örneklerinin duyusal analiz sonuçları Table 7. Sensory analysis results of leather Tulum cheese samples

\begin{tabular}{lcccc}
\hline Özellikler & Minimum & Maksimum & Ortalama & Standart Sapma \\
\hline Kesit ve görünüş $(25 \mathrm{p})$ & 16.50 & 23.25 & 20.31 & 1.85042 \\
\hline Yap1 $(25 \mathrm{p})$ & 17.75 & 24.50 & 21.03 & 2.01718 \\
\hline Koku $(25 \mathrm{p})$ & 16.00 & 24.25 & 21.02 & 2.73618 \\
\hline Tat $(25 \mathrm{p})$ & 14.50 & 24.75 & 21.08 & 2.93794 \\
\hline Toplam $(100 \mathrm{p})$ & 65.00 & 96.75 & 83.44 & 2.38543 \\
\hline
\end{tabular}

Deri Tulum peynirlerinin duyusal analizinde toplam puan 65.00-96.75 arasinda, ortalama 83.44 olarak belirlenmiştir. Plastik bidon Tulum peynirlerinin duyusal analizinde toplam puan 68.25-98.25 arasında, ortalama 86.49 olarak belirlenmiştir. Deri Tulum peynirleri ve plastik bidon Tulum peynirleri duyusal olarak bir arada 
değerlendirildiğinde minimum, maksimum ve ortalama puanlar açısından (Kesit ve görünüş, yapı, koku, tat ve toplam puan) plastik bidon Tulum peynirlerinin deri Tulum peynirlerine göre daha yüksek puan aldığı belirlenmiştir.

Duyusal analiz sonuçları ile tüm örnekler genel olarak karşılaştırıldığında asitlik ile duyusal analiz sonuçları

Çizelge 8. Plastik bidon peynir örneklerinin duyusal analiz sonuçları

Table 8. Sensory analysis results of cheese samples in plastic drums

\begin{tabular}{lccll}
\hline Özellikler & Minimum & Maksimum & Ortalama & Standart Sapma \\
\hline Kesit ve görünüş $(25 \mathrm{p})$ & 17.25 & 24.25 & 21.17 & 1.45464 \\
\hline Yap1 $(25 \mathrm{p})$ & 18.25 & 24.75 & 21.55 & 1.99194 \\
\hline Koku $(25 \mathrm{p})$ & 17.25 & 24.50 & 21.92 & 1.97561 \\
\hline Tat $(25 \mathrm{p})$ & 16.00 & 24.75 & 21.85 & 2.27643 \\
\hline Toplam $(100 \mathrm{p})$ & 68.25 & 98.25 & 86.49 & 1.92465 \\
\hline
\end{tabular}

arasında yüksek düzeyde doğrudan bir ilişki olduğu gözlenirken $(r=0,903) \mathrm{pH}$ ile ters bir ilişki söz konusudur ( $\mathrm{r}=-$ 0,561). Ancak içerdiği tuz miktarı ve yağ miktarı ile duyusal analiz sonuçları arasında anlamlı bir ilişki bulunmamıştır $(\mathrm{p}>0,05)$. Kuru maddede yağ oranı ile duyusal analiz sonuçları arasındaki ilişki incelendiğinde doğrusal bir ilişki $(0,396<r<0,526)$ tespit edilmiş olup toplam kuru madde, yağ, tuz ve kuru maddede tuz miktarında anlamlı bir ilişki tespit edilmemiştir $(\mathrm{p}>0,05)$. Asitlik oranı ile ile duyusal analiz sonuçları arasında kuvvetli bir doğrusal bir ilişki $(0,870<\mathrm{r}<0,898)$ tespit edilmiş olup $\mathrm{pH}$ ile ters orantılı bir ilişki mevcuttur $(-0,758<\mathrm{r}<-0,659)$.

Deri Tulum ve plastik bidon Tulum peynirleri ayrı ayrı incelendiğinde ise deri Tulum peyniri ile asitlik arasında yüksek düzeyde bir ilişki $(\mathrm{r}=0,898)$ ve kuru maddede yağ içeriği ile doğrusal bir ilişki $(\mathrm{r}=0,472)$ tespit edilmişken diğer kimyasal analiz sonuçları ile anlamlı bir ilişkisi söz konusu değildir. Plastik bidondaki Tulum örneklerinin duyusal analizi sonuçları ile toplam kuru madde, yağ, kuru maddede yă̆, protein, tuz, kuru maddede tuz oranları ile anlamlı bir ilişki bulunmamaktadır $(\mathrm{p}>0,05)$. Deri Tulum örneklerinde olduğu gibi asitlik ile duyusal sonuçları(kesit/görünüş, yapı, koku ve tat açısından) arasında kuvvetli bir doğrusal ilişki söz konusudur $(0,907<\mathrm{r}<0,955)$. pH'da ise sadece kesit görünüş özelliğinde düşük düzeyde bir ilişki saptanmıştır $(\mathrm{r}=-0,379)$.

\section{Sonuç}

Ülkemiz değişik peynirler bakımından önemli bir çeşitliliğe sahiptir. Tulum peyniri ülkemizde üretiminde salamuralı ve kuru üretim gibi farklı yöntemler uygulanmakla birlikte, olgunlaştırma, ambalaj ve satış materyali olarak bez, deri Tulum ve plastik bidon gibi farklı materyaller de kullanılmaktadır. Tulum peyniri, ülkemizde en çok üretilen ve tüketilen peynir çeşitlerinden birisidir. Ancak üretiminde ortak bir yöntem olamayışı, değişik hayvan sütlerinden üretilmesi ve gerekli hijyenik koşulların sağlanamaması gibi nedenlere bağlı olarak çok farklı özelliklerde peynir üretilmekte ve bazen de ekonomik kayıplara neden olmaktadır. Araştırma sonucunda deri Tulum ve plastik bidon Tulum peynirlerinin fiziksel ve kimyasal analizleri sonucunda bileşimlerinin çok geniş aralıklarla değiştiği belirlenmiştir. Mikrobiyolojik özellikleri açısından değerlendirildiğinde fazla sayıda mikroorganizma içerdikleri belirlenmiştir. Bu sonuçlar üretimde standart bir yöntem olmadığının, üretiminde ve depolanmasında hijyenik koşullara uyulmadığının göstergesi olarak yorumlanabilir. Ancak kullanılacak ve geliştirilecek üretim yöntemleri ürünün kendine has özelliklerinde büyük değişiklikler yapmadan uygulanmalı, bu konuda daha kapsamlı araştırmalar yapılmalıdır. Bu sayede ülkemize özgü geleneksel lezzetler korunurken, ülke ekonomisine de katma değer sağlanacaktır. Ülkemize özgü yöresel peynirlerle ilgili çok sayıda araştırma yapılmasına karşın, birçok peynir çeşidinde standart bir üretim yöntemi bulunmamaktadır.

\section{Kaynaklar}

Adıgüzel, G., Atasever, M., Karakaya, Y., Aydemir, M., Ünsal, C., 2009. Chemical, microbiological and sensorial properties of Tulum Cheese. Asian Journal of Chemistry, 21 (1): 572-580.

Akyüz, N., 1981. Erzincan (Şavak) Tulum peynirinin yapılışı ve bileşimi. Atatürk Üniversitesi Ziraat Fakültesi Dergisi, 12, 85-112.

Andrews, W.H., Flowers, R.S., Silliker, J., Bailey, J.S., 2001. Salmonella. Compendium of methods for the microbiological examination of foods, 4th ed. (ed. Downes F.P., Ito K.) American Public Health Association, Washington, D.C., 600s. 
Anonim., 2011. Türk gıda kodeksi mikrobiyolojik kriterler yönetmeliği. Resmi Gazete Tarihi: 29.12.2011, Resmi Gazete Sayısı: 28157 (3.mükerrer), Gıda Tarım ve Hayvancılık Bakanlığı, Ankara.

Anonim., 2015. Türk gıda kodeksi peynir tebliği (Tebliğ No: 2015/6). 29261 Sayılı Resmî Gazete. Gıda Tarım ve Hayvancılık Bakanlığı, Ankara.

AOAC, 1995. Official Methods of Analysis, (Moisture in Nuts and Nuts Products). Association of Official Analytical Chemists, Washington, DC, USA.

AOAC, 1997. Official Methods of Analysis, 16th ed. Arlington: Association of Official Analytical Chemists.

Arıcı, M, Şimşek, O., 1991. Kültür kullanımının Tulum peynirinin duyusal, fiziksel, kimyasal ve mikrobiyolojik özelliklerine etkisi. Gida, 16, (1), 53-62.

Arslaner, A., Turkmen, O., 2020. Erzincan Tulum cheese. Turkish JAF Sci. Tech., 8(4): 932-940.

Ateş, G, Patır, B., 2001. Starter kültürlü Tulum peynirinin olgunlaşması sırasında duyusal kimyasal ve mikrobiyolojik niteliklerinde meydana gelen değişimler üzerine araştırmalar. FÜ Sağ. Bil. Derg., 15, (1), 45-46.

Aydar, L.Y., 1999. Gıdalarda maya ve küf sayımı. Gıda Mikrobiyolojisi ve Uygulamaları. Armani Matbaacılık, Ankara, 296s.

Azak, M. G., Kılıç, H., Hızlısoy, H., Abay, S., 2012. Erzincan ili Tulum peynirlerinden Listeria spp. izolasyonu ve identifikasyonu. Erciyes Üniv. Vet. Fak. Derg., 9(3): 149-156.

Caridi, A., 2003. Identification and first characterization of lactic acid bacteria isolated from artisanal ovine cheese Pecorino del Poro. International Journal of Dairy Technology, 56: 105-110.

Cemeroğlu, B., 2010. Gıda analizlerinde genel yöntemler. Gıda Analizleri (editör: Cemeroğlu B.). Gıda Teknolojisi Derneği Yayınları, No:34, Ankara, 535s.

Çalım, H.D., 2007. Konya ve çevresinde farklı tip ambalajlarda tüketime sunulan Tulum peynirlerinin kalite nitelikleri. Doktora Tezi, Selçuk Üniversitesi Sağlık Bilimleri Enstitüsü, Besin Hijyeni ve Teknolojisi Anabilim Dalı, Konya, 130s.

Çakır, Y., Çakmakçı, S. 2018. Some microbiological, physicochemical and ripening properties of Erzincan Tulum cheese produced with added black cumin (Nigella Sativa L.). Journal of Food Science and Technology, 55(4), 1435-1443.

Demir, P, Öksüztepe, G, İncili, KG. 2017., Vakum paketli Şavak Tulum peynirlerinde potasyum sorbatın kullanımı. Kafkas Üniv. Vet. Fak. Derg., 23(1): 23-30.

Demir, P., Erkan, S., Öksüztepe, G., 2018. Elazığ'da satılan Şavak Tulum peynirlerinin mikrobiyolojik kalitesi. Harran Üniv. Vet. Fak. Derg., 7(1): 15-20.

Demirtaş, M., Coşkun, H., 2018. Keçi sütünden farklı pihtılaştırma yöntemleri ile üretilen Tulum peynirlerinin olgunlaştırılması esnasında meydana gelen değişmeler. Gıda (2018) 43 (5): 835-845.

Dinkçi, N., Ünal, G., Akalın, S., Varol, S., Gönç, S., 2012. Kargı Tulum peynirinin kimyasal ve mikrobiyolojik özellikleri. Ege Üniversitesi Ziraat Fakültesi Dergisi, 49 (3): 287-292.

Duman Aydın, B., Gülmez, M. 2008. Erzincan Tulum peyniri üretiminde alternatif yöntemlerin araştırılması. Kafkas. Üniv. Vet. Fak. Derg. 14: 67-73.

Durlu Özkaya, F., Gün, İ., 2017. Anadolu'da peynir kültürü. Uluslararası Asya ve Kuzey Afrika Çalışmaları Kongresi Kitabı, 10-15 Eylül, Ankara, Türkiye. 485-505.

Erceyes, Ö., Yıldırım, M., Yıldırım, Z., 2018. Tulum peynirinin toplam karbonil madde içeriği ile bazı kimyasal ve mikrobiyolojik nitelikleri. Journal of Animal Science and Product 1 (1) 67-83.

Erdoğan, A., Gürses, M., Sert, S., 2003. Isolation of moulds capable of producing mycotoxins from blue mouldy Tulum cheeses produced in Turkey. International Journal of Food Microbiology, 85: 83-85.

Eser, S., Coşkun, H., Sarıca, E., 2020. Kefir starteri kullanılarak üretilen Tulum peynirlerinde olgunlaşma boyunca meydana gelen değișmeler. Gıda,45 (4): 710-720.

Goto, S., Enomoto, S., 1970. Nalidixic acid cetrimide agar. A new selective plating medium for the selective isolation of Pseudomonas aeruginosa. Japan Journal of Microbiology, 14, 65-72.

Halkman, AK., 2005. Merck Gıda Mikrobiyolojisi Uygulamaları. Başak Matbaacılık, Ankara.

Hayaloğlu, A.A., Fox, P.F., Güven, M., Çakmakçı, S., 2007. Cheeses of Turkey: 1. Varieties ripened in goat-skin bags. Lait, 87: 79-95.

Kamber, U., 2006. Peynirin tarihçesi. Veteriner Hekimler Derneği Dergisi, Cilt: 77 - Sayı: 2, 40-44.

Kiraz, Ş., 2018. Çorum yöresinde üretilen geleneksel Kargı Tulum peynirlerinin bazı bileşim özelliklerinin belirlenmesi. Hitit Üniversitesi Fen Bilimleri Enstitüsü Gıda Mühendisliği Anabilim Dalı Yüksek Lisans Tezi, Çorum, Türkiye, $45 \mathrm{~s}$.

Morul, F., İşleyici, Ö., 2012. Divle Tulum peynirinin kimyasal ve mikrobiyolojik özellikleri. YYÜ Vet. Fak. Derg., 23: 71-76.

Nyachuba D.G., Donnely C.W., 2007. Comparison of 3M petrifilm environmental Listeria plates against Standard enrichment methods for the detection of Listeria monocytogenes of epidemiological significance from environmental surfaces. Journal of Food Science. 72, 9, 346-354. 
Oysun, G., 1991. Süt Ürünlerinde Analiz Yöntemleri, Ege Üniv Zir Fak Ofset Basımevi, İzmir.

Öner, Z., Karahan, A.G., Aloğlu, H., 2005. Starter kültür kullanılarak yapılan Tulum peynirlerinin bazı özellikleri. Gida, 30 (1): 57-62.

Rençber, F., Çelik, Ş., 2021. Farklı ambalaj materyalinde olgunlaştırılan Muş Tulum peynirinin bazı karakteristik özellikleri. Atatürk Üniv. Ziraat Fak. Derg., 52 (1): 1-10.

Sancak, H., İşleyici, Ö., Tuncay, R. M., Sancak, Y. C., 2018. Geleneksel olarak üretilen Bitlis Tulum peyniri ve kimyasal kalite nitelikleri. BEÜ Fen Bilimleri Dergisi, 7(2): 380-389.

Saygıl1, D., Demirci, H., Samav, U., 2020. Coğrafi işaretli Türkiye peynirleri. Aydın Gastronomy, 4(1), 11-21.

Sert, D., Akın, N., 2008. Türkiye'de bazı önemli Tulum peyniri çeşitlerinin geleneksel üretim metotları. Türkiye 10. Gida Kongresi; 21-23 Mayis 2008, Erzurum, 717-720.

Schraft H., Watterworth L. A., 2005. Enumeration of heterotrophs, fecal coliforms and Escherichia coli in water: comparison of 3M Petrifilm plates with standard plating procedures. Journal of Microbiological Methods, 60, $335-342$.

Silbernagel, K.M., Lindberg K.G., 2003. 3M Petrifilm Enterobacteriaceae count plate method for enumeration of Enterobacteriaceae in selected foods: collaborative study. Journal of AOAC International, 86, 4, 802-814.

Silva, B.O., Caraviello, D.Z., Rodrigues, A.C., Ruegg P.L., 2005. Evaluation of petrifilm for the 1solation of Staphylococcus aureus from milk samples. Journal of Dairy Science, 88, 8, 3000-3008.

Tarakçı, Z., Küçüköner, E., Sancak, H., Ekici, K., 2005. İnek sütünden üretilerek cam kavanozlarda olgunlaştırılan Tulum peynirinin bazı özellikleri. YYÜ Vet. Fak. Derg., 16:9-14.

Tekin, A., Güler, Z., 2019. Glycolysis, lipolysis and proteolysis in raw sheep milk Tulum cheese during production and ripening: Effect of ripening materials. Food Chemistry, 286, 160-169.

Tekinşen, K. K., Akar, D., 2017. Erzincan Tulum peyniri. Atatürk Üniversitesi Vet. Bil. Derg., 12(2): 218-226.

Tomar, O., 2019. The effects of probiotic cultures on the organic acid content, texture profile and sensory attributes of Tulum cheese. International Journal of Dairy Technology, 72 (2), 218-228.

Tomar, O., Akarca, G., Beykaya, M., Çağlar, A., 2018. Some characteristics of Erzincan Tulum cheese produced using different probiotic cultures and packaging material. Kafkas Üniversitesi Veteriner Fakültesi Dergisi, 24, 647-654.

Toklu, S., Pekerşen, Y., 2019. Coğrafi işaretli gastronomik bir değer olan Karaman Divle Obruğu Tulum peynirinin bölge halk1 tarafindan algılanması. Journal of Tourism and Gastronomy Studies, 7(3), 2251-2273.

Tulukoğlu, G.B., Akan, E., Kınık, Ö., 2020. İzmir Tulum peyniri üretiminde peynir altı suyu kültürü kullanımı. Ege Üniv. Ziraat Fak. Derg., 57 (3):441-453.

Ünlütürk, A., Turantaş F., 2002. Gıdaların mikrobiyolojik analizleri. Meta Basım Matbaacılık Hizmetleri, İzmir, 186s.

Yerlikaya, O., Kınık, Ö., 2013. Türkiye'de üretilen ve tüketilen Tulum peyniri çeşitlerimiz. Dünya Gıda, Cilt.5, 7581.

Yerlikaya, O., 2018. Ege ve Marmara bölgesi’nde üretilen ve tüketime sunulan beyaz peynirlerin bazı mikrobiyolojik özelliklerinin incelenmesi üzerine bir araştırma. Ege Üniv. Ziraat Fak. Derg., 55 (4):499-505. 